\title{
URGENSI PENGATURAN PERKARA CONSTITUTIONAL COMPLAINT DALAM KEWENANGAN MAHKAMAH KONSTITUSI
}

\author{
Oleh: Rahmat Muhajir Nugroho \\ Fakultas Hukum Universitas Ahmad Dahlan \\ E-mail: rahmat.nugroho@law.uad.ac.id
}

\begin{abstract}
This study aimed to evaluate the mechanism for settling disputes in the Constitutional Court containing elements of constitutional complaint. In particular, this study focused on two things: first assessing the urgency/ importance of the idea of setting constitutional complaint in the Constitutional Court's authority. Secondly, to formulate recommendations on setting constitutional complaint in the Constitutional Court's authority.

The method used in this research is descriptive qualitative. This type of research is a doctrinal law. This research studied the concept and implementation of the judicial settlement of cases that contain elements of constitutional complaint (complaint constitution) by the Constitutional Court.

The conclusion of this study is an important constitutional complaint mechanism is contained within the competence of the Constitutional Court to solve problems of injustice experienced by citizens as a result of public policies undertaken by the government in a broad sense, namely the executive, legislature and judiciary. Setting constitutional complaint within the competence of the Constitutional Court does not have to be explicitly stipulated in the constitution, but enough in the explanation of the Constitutional Court Act. That is not to add direct authority of the Court, but expand the meaning of the authority of the Court in testing the law.
\end{abstract}

Keywords: Urgency, Constitutional complaint, Constitutional Court

\section{A. LATAR BELAKANG}

Kewenangan Mahkamah Konstitusi diatur dalam Pasal 24C ayat (1) UndangUndang Dasar 1945 yang berbunyi "Mahkamah Konstitusi berwenang mengadili pada tingkat pertama dan terakhir yang putusannya bersifat final untuk menguji undang-undang terhadap Undang-Undang Dasar, memutus sengketa kewenangan lembaga negara yang kewenangannya diberikan oleh Undang-Undang Dasar, memutus pem-bubaran partai politik dan memutus perselisihan tentang hasil pemilihan umum". Selain memiliki beberapa kewenangan tersebut, Mahkamah Konstitusi juga memiliki satu kewajiban yaitu memberikan putusan atas pendapat Dewan Perwakilan Rakyat mengenai dugaan pelanggaran oleh Presiden dan/atau Wakil Presiden menurut Undang-Undang Dasar (Pasal 24 C ayat (2) UUD 1945).

Dalam rangka memperkuat perlindungan terhadap hak-hak konstitusional warga negara, maka kewenangan Mahkamah Konstitusi perlu diperluas, dengan memasukkan mekanisme constitutional complaint ke dalam salah satu kewenangan Mahkamah Konstitusi. Penambahan kewenangan ini berfungsi untuk melindungi 
hak-hak warga negara yang berpotensi dilanggar oleh tindakan atau kebijakan yang di-keluarkan pemerintah (eksekutif), Dewan Perwakilan Rakyat (legislatif) serta putu-san pengadilan (yudikatif).

Mekanisme constitutional complaint atau dalam bahasa Jerman disebut verfas-sungsbeschwerde merupakan hak yang dimiliki oleh setiap orang atau kelompok tertentu untuk melakukan pernyataan sikap tidak setuju atau menolak terhadap per-lakuan pemerintah terhadapnya. Artinya, orang atau kelompok tertentu tersebut me-rasa hak-hak kosntitusionalnya dilanggar oleh pemerintah. Constitutional complaint memberikan jaminan agar dalam proses-proses menentukan dalam penyelenggaraan negara, baik dalam pembuatan perundangundangan, proses administrasi negara, dan putusan peradilan tidak melanggar hakhak konstitusional (Krisdanar, 2010: 190).

Banyak pengaduan konstitusional yang diajukan ke Mahkamah Konstitusi tidak dapat terselesaikan. Meskipun Mahkamah Konstitusi kerap melakukan sidang berkaitan dengan pelanggaran terhadap konstitusi yang masuk dalam kewenangannya. Namun, terdapat hal mendasar yang masih mengganjal dibenak pencari keadilan, yaitu belum terbukanya fungsi Mahkamah Konstitusi selaku lembaga yang dapat me-nampung dan menyalurkan keluh kesah (personal grievance) atau pengaduan konsti-tusional sebagai upaya yang luar biasa dalam mempertahankan hak-hak konsti-tusional bagi setiap warga negara, atau lebih dikenal dengan istilah constitutional complaint (Aditya, 2014: 39).

Salah satu contoh kasus yang dapat dikategorikan sebagai perkara constitutional complain adalah kasus Surat Keputusan Bersama (SKB) Tentang Ahmadiyah. Secara yuridis, produk hukum berupa SKB sulit untuk diperkarakan. SKB tidak dapat diajukan judicial review ke MK, karena MK hanya berwenang menguji Undang-Un-dang terhadap UUD. Begitu pula ke Mahkamah Agung, tidak terdapat kewenangan MA untuk menguji produk hukum berupa SKB, sebab SKB bukan bagian dari peraturan perundang-undangan yang dapat diuji oleh MA, sebagaiamana tercantum dalam hierarki perundang-undangan yang diatur Undangundang No. 12 tahun 2011. Selan-jutnya, jika digugat ke Peradilan Tata Usaha Negara (PTUN) tidak tepat pula, sebab substansi yang tercantum dalam SKB tersebut berupa pengaturan bukan penetapan karena muatannya bersifat umum (Mahfud MD, 2009: 287).

Hal tersebut merupakan salah satu masalah yang perlu diselesaikan, agar tidak terulang kembali di masa yang akan datang, tentang bagaimana cara penyelesaian masalah tersebut dan kemanakah warga negara dapat mengadukan persoalannya. Sementara ini, belum ada mekanisme peradilan untuk menyelesaikan per-kara yang disebut dengan constitutional complaint. Mahkamah Konstitusi masih ter-batas pada empat kewenangan dan satu kewajiban yang dimiliki sebagaiamana ter-cantum dalam UUD 1945. Oleh karena itu, penulis tertarik untuk meneliti permasalahan ini dan mencari solusi dengan mengkaitkan fungsi Mahkamah Konstitusi sebagai the guardian of constitution (pengawal konstitusi) dan the protector of the citizent's constitutional rights (pelindung hak konstitusional warga Negara). 
Berdasarkan latar belakang masalah di atas, maka penulis menyusun rumusan masalah sebagai berikut:

1. Apa urgensi gagasan pengaturan constitutional complaint dalam kewenangan Mahkamah Konstitusi?

2. Bagaimanakah rumusan pengaturan constitutional complaint dalam kewenangan Mahkamah Konstitusi?

\section{B. METODE PENELITIAN}

Tipe penelitian ini adalah penelitian hukum doktrinal, artinya penelitian ini mempelajari konsep dan implementasi penyelesaian perkara judicial review yang mengandung unsur constitutional complaint (keluhan konstitusi) oleh Mahkamah Konstitusi.

Penelitian ini dilaksanakan dengan menggunakan pendekatan deskriptif kual-itatif. Lokasi penelitian dilaksanakan di Yogyakarta dan Jakarta sebagai tempat utama untuk mengumpulkan data primer dan sekunder.

Data yang dikumpulkan dalam penelitian kepustakaan antara lain jurnal, majalah, buku-buku, surat kabar, peraturan perundang-undangan, putusan MK, internet dan segala materi sekunder terkait dengan kewenangan MK. Selain itu, untuk menguji akurasi data, maka akan dilakukan wawancara terhadap pakar hukum dengan dipan-du daftar pertanyaan (bebas terpimpin) yang sudah dipersiapkan sebelumnya dan berkembang pada saat wawancara dilakukan.

Data primer dan data sekunder dianalisis dengan menggunakan analisis kuali-tatif dan deskriptif. Pada tahap ini, beberapa aktivitas dilaksanakan seperti mengum-pulkan kasus-kasus dan putusan-putusan yang diputuskan oleh Mahkamah Konsti-tusi. Melakukan interview dengan ahli hukum tata negara dan mengimplementasikan teori hukum konstitusi, melakukan analisis terhadap hasil wawancara, memetakan permasalahan-permasalahan yang dihadapi Mahkamah Konstitusi dalam menyele-saikan perkara judicial review yang mengandung unsur constitutional complaint, me-rumuskan kesimpulan dan rekomendasi-rekomendasi model kebijakan yang lebih baik dalam penyelesaian perkara constitutional complaint.

\section{TINJAUAN PUSTAKA}

\section{Kekuasaan Kehakiman dan Mahkamah Konstitusi}

Konsep negara hukum dan negara demokrasi yang lahir sebagai saudara kem-bar menyusul zaman Rennaissance di Eropa telah membawa prinsip pemisahan atau pembagian kekuasaan ke dalam organ-organ tersendiri yaitu: legislatif, eksekutif, dan yudikatif. Pembagian kekuasan ke dalam tiga poros yang kemudian dikenal sebagai Trias Politica itu dimaksud untuk mendobrak absolutisme atau sistem pemerintahan yang otoriter (Mahfud, 1999:283). 
Jika analisis tersebut diletakkan dalam konteks ajaran Montesqieu yakni Trias Politica murni, kekuasaan tidak hanya berbeda tetapi juga merupakan suatu institusi yang harus terpisah satu sama lainnya di dalam melaksanakan kewenangannya (KRHN dan LeIP, 1999: X).

Menurut doktrin pemisahan kekuasaan tersebut, fungsi dan kekuasaan kehakiman adalah melakukan kontrol terhadap kekuasaan negara guna mencegah terjadinya proses instrumentasi yang menempatkan hukum menjadi bagian dari kekuasaan (KRHN dan LeIP, 1999:XI).

Untuk dapat disebut sebagai lembaga peradilan haruslah memenuhi persyaratan tertentu, antara lain (Muchsan, 1981:9):

a. Adanya suatu aturan hukum yang abstrak yang mengikat umum, yang dapat diterapkan pada suatu persoalan

b. Adanya suatu perselisihan hukum yang konkret,

c. Adanya suatu aturan peradilan yang berwenang memutuskan perselisihan.

Setelah melihat uraian tentang ajaran pemisahan kekuasaan tersebut, tampak bahwa dalam setiap kekuasaan negara yang menyebut dirinya sebagai negara hukum, maka di dalamnya pasti terdapat kekuasaan kehakiman. Kekuasaan kehakiman ter-sebut haruslah merupakan kekuasaan yang mandiri dan bebas dari intervensi dari pi-hak manapun (Fatkhurohman, et. al., 2004: 14).

Menurut Pasal 24 ayat (1) UUD 1945 disebutkan bahwa "Kekuasaan Kehakiman merupakan kekuasaan yang merdeka untuk menyelenggarakan peradilan guna menegakkan hukum dan keadilan". Dengan demikian, Kekuasaan Kehakiman harus terbebas dari intervensi atau campur tangan dari pihak lain atau lembaga lain baik eksekutif maupun legislatif. Kekuasaan harus berdiri sebagai lembaga yang mandiri dan tidak berada di bawah kekuasaan lembaga lain, agar mampu melaksanakan tugas mulianya dalam menegakkan hukum dan keadilan.

Selanjutnya ayat (2) Pasal 24 UUD 1945 menyebutkan bahwa, "Kekuasaan Ke-hakiman dilakukan oleh sebuah Mahkamah Agung dan peradilan lain yang berada di bawahnya dalam lingkungan peradilan umum, lingkungan peradilan agama, lingkup-ngan peradilan militer, lingkungan peradilan tata usaha negara dan oleh sebuah Mah-kamah Konstitusi".

Berdasarkan pasal 24 ayat (2) UUD 1945 di atas, terdapat 2 (dua) lembaga negara yang memegang kekuasaan kehakiman yaitu Mahkamah Agung dan Mahkamah Konstitusi. Mahkamah Agung merupakan benteng terakhir keadilan, sebab seluruh proses penegakan hukum di peradilan Indonesia berpuncak dan berakhir di Mahkamah Agung. Kewenangan utama Mahkamah Agung adalah mengadili perkara pada tingkat kasasi, melakukan judicial review yaitu menguji peraturan perundangun-dangan di bawah undang-undang terhadap undang-undang, dan mempunyai ada-nang lainnya yang diberikan oleh undang-undang (Pasal 24A (1)). Selain itu, pada proses pengisian jabatan Hakim Konstitusi, Mahkamah Agung memiliki wewenang untuk mengajukan tiga orang anggota Hakim Konstitusi (Pasal 24C (3)), 
sedangkan hubungannya dengan Presiden, Mahkamah Agung memberikan pertimbangan dalam hal Presiden memberi grasi dan rehabilitasi (Pasal 14 (1)).

Selain Mahkamah Agung ada Mahkamah Konstitusi. Mahkamah Konstitusi merupakan lembaga negara yang bertugas mengawal konstitusi (the guardian of contitution), sehingga berwenang untuk mengadili seluruh perkara yang berkaitan dengan pelanggaran konstitusi. "Mahkamah Konstitusi berwenang mengadili pada tingkat pertama dan terakhir yang putusannya bersifat final untuk menguji undangundang terhadap Undang-Undang Dasar, memutus sengketa kewenangan lembaga negara yang kewenangannya diberikan oleh Undang-Undang Dasar, memutus pembubaran partai politik dan memutus perselisihan tentang hasil pemilihan umum" (Pasal 24C ayat(1)). Selain memiliki beberapa kewenangan tersebut, Mahkamah Kon-stitusi juga memiliki satu kewajiban yaitu memberikan putusan atas pendapat Dewan Perwakilan Rakyat mengenai dugaan pelanggaran oleh Presiden dan/atau Wakil Presiden menurut Undang-Undang Dasar (Pasal 24C (2)).

Dari rumusan pasal 24 UUD 1945 di atas, dapat dilihat bahwa rechtsidee pembentukan Mahkamah Konstitusiadalah (Arto, 2001: 145):

a. Kekuasaan kehakiman merupakan kekuasaan negara.

b. Kekuasaan kehakiman merupakan kekuasaan yang merdeka.

c. Ruang lingkup kekuasaan kehakiman adalah menyelenggarakan peradilan guna menegakkan hukum dan keadilan.

d. Mahkamah Konstitusi merupakan salah satu pelaku kekuasaan kehakiman.

Keberadaan Mahkamah Konstitusi yang telah diletakkan dalam bidang kekuasaan kehakiman bisa dikatakan telah sejalan dengan perubahan paradigma ketatanegaraan yang terjadi dalam perubahan Undang-Undang Dasar 1945.

Mahkamah Konstitusi dibentuk untuk menjamin agar konstitusi sebagai hukum tertinggi dapat ditegakkan sebagaimana mestinya. Kelahiran Mahkamah Konsti-tusi tidak saja membuktikan bahwa Indonesia menganut kekuasaan kehakiman yang bebas dan merdeka akan tetapi sekaligus merupakan penegasan terhadap prinsip negara hukum yang demokratis (Lutfi, 2010: 5).

Keberadaan Mahkamah Konstitusi dalam sistem ketatanegaraan Republik Indonesia, sekaligus memperlihatkan adanya harapan baru bagi para pencari keadilan di tengah masyarakat yang sedang mengalami krisis kepercayaan terhadap institusi peradilan. Keberadaan Mahkamah Konstitusi merupakan suatu bentuk upaya da-lam mengimbangi atas kekuasaan legislatif maupun kekuasaan eksekutif, karena ke-beradaan Mahkamah Konstitusi tersebut memiliki kewenangan yang diberikan oleh UUD 1945. Keberadaan Mahkamah Konstitusi di Indonesia dilatarbelakangi adanya kehendak untuk membangun pemerintahan yang demokratis dengan checks and ba-lances system di antara cabang-cabang kekuasaan, mewujudkan supremasi hukum dan keadilan, serta menjamin dan melindungi hak-hak konstitusional warga negara. Selain itu, pembentukan Mahkamah Konstitusi dimaksudkan sebagai sarana penye-lesaian beberapa problem yang terjadi dalam praktik ketatanegaraan yang sebelum-nya tidak ditentukan oleh konstitusi (Lutfi, 2010: 6). 
Mahkamah Konstitusi merupakah salah satu pelaku kekuasaan kehakiman, disamping Mahkamah Agung sebagaimana dimaksud dalam Pasal 24 ayat (1) dan ayat (2) Undang-Undang Dasar Negara Republik Indonesia 1945. Hal ini berarti Mah-kamah Konstitusi terikat pada prinsip umum penyelenggaraan kekuasaan kehakiman yang bebas merdeka, bebas dari pengaruh kekuasaan lembaga lainnya dalam me-negakkan hukum dan keadilan (Sutiyoso, 2009: 5).

Perubahan Pasal 24 UUD 1945 juga tidak lagi menempatkan Mahkamah Agung sebagai single top authority dalam kekuasaan kehakiman, karena kehadiran Mahkamah Konstitusi dengan kewenangan konstitusional yang diatur dalam Pasal 24C (Fajar, 2006: 114-115). Sedangkan tugas dan fungsi Mahkamah Konstitusi menurut Penjelasan Umum Undang-Undang Nomor 24 tahun 2003 tentang Mahkamah Konsitusi adalah menangani perkara ketatanegaraan atau perkara konstitusi tertentu dalam rangka menjaga konstitusi (UUD 1945), agar dilaksanakan secara bertanggung jawab sesuai dengan kehendak rakyat dan cita-cita demokrasi. Keberadaan Mahka-mah Konstitusi sekaligus untuk menjaga terselenggaranya pemerintahan negara yang stabil, dan juga merupakan koreksi terhadap pengalaman kehidupan ketatanegaraan di masa lalu yang ditimbulkan oleh tafsir ganda terhadap konstitusi. Oleh karena itu, selain sebagai penjaga konstitusi (the guardian of the contitution), Mahkamah Konsti-tusi juga merupakan penafsir tertinggi konstitusi (the sole interpreter of contitution) (Fajar, 2006: 114-115).

\section{Perlindungan HAM dalam Konstitusi}

Hak konstitusional warga negara adalah hak yang dijamin oleh negara yang dalam hal ini adalah pemerintah sebagaimana yang termaktub didalam UUD 1945. Hestu Cipto Handoyo (2003: 272) mengemukakan konstitusi dibentuk sejatinya adalah untuk membatasi kekuasaan, agar tidak diterapkan secara sewenangwenang. Dengan demikian, dapatdikatakan bahwa konstitusi sangat menjunjung tinggi hak asasi manusia dan hak-hak warga negara agar terhindar dari kesewenang-wenangan pemerintah yang dapat merugikan hak warga negara.

Negara Indonesia adalah negara Welfare State (negara kesejahteraan), sebagaimana disebutkan dalam Pembukaan UUD 1945 Alinea ke-IV dengan kalimat "memajukan kesejahateraan umum" membawa konsekuensi bahwa negara (pemerintah) harus aktif memberikan perlindungan dan jaminan kepada warganya. Adapun salah satu ciri negara Welfare State yaitu adanya perlindungan konstitusional, dalam arti bahwa konstitusi selain menjamin hak-hak individu harus menentukan juga cara prosedural untuk memperoleh perlindungan atas yang dijamin itu (Marbun, 2009: 38).

Mengingat pentingnya penegakan hak asasi manusia dan hak warga negara sebagaimana yang dijamin oleh konstitusi sehingga pemerintah dituntut untuk mem-berikan jaminan dan mewadahi setiap serta menyelesaikan setiap pelanggaran baik yang dilakukan oleh eksekutif, legislatif maupun yudikatif yang dianggap merugikan hak warga negara. 


\section{Constitutional Complaint}

Menurut Herman Schwartz yang dikutip dari Maruarar Siahaan (2012: 3) menjelaskan tentang berdirinya Mahkamah Konstitusi sebagai special tribunal secara terpisah dari Mahkamah Agung, yang mengemban tugas khusus, merupakan konsepsi yang dapat ditelusuri jauh sebelum negara kebangsaan yang modern (modern nation-state), yang pada dasarnya menguji keserasian norma hukum yang lebih rendah deng-an norma hukum yang lebih tinggi. Sejarah modern judicial review, yang merupakan konsepsi yang dapat ditelusuri jauh sebelum negara kebangsaaan modern (modern nation-state), pada dasarnya menguji keserasian norma hukum yang lebih rendah dengan norma hukum yang lebih tinggi. Sejarah modern judicial review sebagai ciri utama kewenangan Mahkamah Konstitusi -di Amerika Serikat oleh Mahkamah Agung- dapat dilihat sebagai perkembangan yang berlangsung selama 250 tahun, dengan rasa kebencian sampai dengan penerimaan yang luas.

Salah satu ciri dari negara hukum adalah adanya jaminan penegakan dan perlidungan terhadap hak-hak konstitusional warga negara. Mahkamah Konstitusi di Indonesia merupakan lembaga yang berdiri pada tahun 2003. Indonesia merupakan negara ke-78 yang mengadopsi gagasan pembentukan Mahkamah Konstitusi yang berdiri sendiri ini, setelah Austria pada tahun 1920, Italia pada tahun 1947, dan Jer-man pada tahun 1948 (Asshiddiqie, 2011: 194).

Kewenangan Mahkamah Konstitusi, selain tercantum dalam UUD 1945, lebih lanjut diatur didalamPasal 10 ayat (1) Undang-undang No 24 Tahun 2003 tentang Mahkamah Konstitusi, yaitu:

a. Menguji undang-undang terhadap Undang-Undang Dasar negara Republik Indonesia Tahun 1945.

b. Memutus sengketa kewenangan lembaga negara yang kewenangannya diberikan oleh Undang-Undang Dasar 1945.

c. Memutus pembubaran partai politik.

d. Memutus perselisihan hasil pemiihan umum.

Selain memilik kewenagan, Mahkamah Konstitusi juga memiliki kewajiban sebagaimana dalamPasal 10 ayat (2) Undang-Undang No.24 tahun 2003 Tentang Mahkamah Konstitusi yaitu "Mahkamah Konstitusi wajib memberikan putusan atas pendapat DPR bahwa presiden dan/atau wakil presiden diduga telah melakukan pelanggaran hukum berupa pengkhianatan terhadap negara, korupsi, penyuapan, tindak pidana berat lainnya, atau perbuatan tercela, dan/atau tidak lagi memenuhi syarat sebagai Presiden dan/atau Wakil Presiden sebagaimana dimaksud dalam Undang-Undang Dasar Negara Republik Indonesia Tahun 1945.

Meskipun judicial review telah menjadi kewenangan Mahkamah Konstitusi namun hal ini hanya terbatas pada produk DPR (Undang-undang) sehingga tindakan-tindakan (kebijakan) baik pemerintah (eksekutif), legislatif, atau yudikatif yang berpotensi merugikan hak warga yang telah dijamin oleh konstisusi khususnya hak yang bersifat fundamental rights belum terlindungi secara baik. 
Pada negara yang menganut paham negara demokrasi, seperti halnya di Indonesia, mekanisme constitusional complaintmenjadi sangat penting untuk diatur. Hal tersebut dilakukan dalam rangka menjamin hak-hak konstitusional warga negara yang sebagaimana tercantum dalam UUD 1945 pasal 28A sampai pasal 28J. Mekanis-me ini diperlukan karena hak konstitusional masyarakat tidak hanya berpotensi dilanggar dengan berlakunya sebuah undang-undang sehingga hanya disediakan mekanisme judicial review, namun hak warganegara tentunya juga sangat berpotensi dirugikan dengan adanya tindakan (kebijakan) yang dikeluarkan oleh kekuasaan eksekutif (pemerintah), DPR (legislatif), serta pelanggaran yang dikeluarkan oleh kekuasaan kehakiman.

Meskipun Mahkamah Konstitusi hanya diberi wewenang judicial review terhadap undang-undang, tetapidalam praktik, banyak perkara yang diajukan ke Mahkamah Konstitusi secara formal dalam bentuk pengujian undang-undang, tetapi seca-ra substansial termasuk pengaduan konstitusional (constitutional complaint dan con-stitutional questions). Secara definisi umum constitutional complaint adalah bentuk pengaduan warga negara melalui proses ajudikasi di pengadilan atas tindakan (kebi-jakan) atau pengabaian oleh negara, dalam hal ini lembaga-lembaga negara yang me-langgar hak-hak warga negara yang dijamin konstitusi. Seperti perkara-perkara yang mempermasalahkan implementasi undang-undang, penyimpangan proses penega-kan hukum, putusan peradilan umum yang dianggap melanggar konstitusi, dan seba-gainya, termasuk perkara yang cukup terkenal yaitu kasus dugaan kriminalisasi Pim-pinan Komisi Pemberantasan Korupsi (KPK), Bibit Samad Rianto dan Candra Hamzah (Zoelva, 2012: 154)

Melihat fakta-fakta diatas, pentingnya memasukkan konsep constitutional complaint sebagai salah satu kewenangan Mahkamah Konstitusi Indonesia merupakan sebuah langkah konkret dan riil dalam rangka mengantisipasi tindakan pemerin-tah (eksekutif), DPR, maupun putusan peradilan yang mampu merugikan hak warga negara yang telah dijamin oleh konstitusi.

Hal ini mampu dilakukan dengan melihat tatacara implementasi mekanisme constitutinal complaint di negara Federal Jerman, di mana negara Jerman dan Indone-sia menganut sistem hukum yang sama, yaitu menganut Civil Law. Pengadilan Konsti-tusi Jerman merupakan salah satu pengadilan yang secara jelas menerapkan mekanis-me constitutional complaint sebagai salah satu kewenangannya. Hal tersebut dapat kita lihat pada kasus larangan penyembelihan hewan yang digugat oleh kaum muslim Jerman dengan alasan kebebasan dalam hal beragama dan melaksanakan peribada-tan sesuai dengan keyakinan. Dari sisi hukum, aturan pelarangan penyembelihan hewan kurban tersebut tidak melanggar konstitusi, sehingga tidak dapat diuji ke Mah-kamah Konstitusi Jerman. Tetapi dari sisi hak asasi manusia, larangan tersebut melanggar kebebasan beragama, dan hal tersebut masuk dalam objek perkara consti-tutional complaint.

Mekanisme constitutional complaint di Negara Federal Jerman telah diatur da-lam ketentuan Pasal 93 ayat (1) Angka 4a dan 4b Grundgesets, disebutkan bahwa 
per-orangan warga negara maupun kelompok dapat mengajukan keluhan atau pengadu-an kepada Mahkamah konstitusi (Aditya, 2014: 44).

Dari apa yang dijelaskan di atas maka menurut penulis perbedaan antara constitutional complaint dengan judicial review sebagaimana yang di terapkan di Indonesia tidak begitu berbeda, yang berbeda adalah hanya mengenai penempatan dalam hal objek yang dimohonkan. Pada mekanisme judicial review, objeknya adalah berlakunya aturan undang-undang yang dianggap merugikan hak warga Negara sedangkan pada mekanisme constitutional complaint objeknya adalah tindakan (kebi-jakan) pemerintah, DPR dan putusan pengadilan yang merugikan hak-hak warga negara.

Dengan demikian, dapat dikatakan bahwa objek dari mekanisme constitutional complaint sangat luas dibandingkan judicial review. Namun, secara eksplisit kewenangan Mahkamah Konstitusi sebagaimana diatur didalam Undang-Undang no 24 Tahun 2003 tentang Mahkamah Konstitusi membatasi kewenangan Mahkamah Konstitusihanyapadapengujianundang-undang (judicial review). Oleh karena itu diperlukan terobosan baru, untuk mengatur mekanisme constitutional complaint dalam peraturan perundang-undangan demi melindungi hak-hak konstitusional warga negara.

\section{PEMBAHASAN HASIL PENELITIAN}

\section{Urgensi Pengaturan Constitutional Complaint dalam Kewenangan Mahkamah Konstitusi.}

Secara khusus contitutional complaint atau pengaduan konstitusional merupakan bentuk pengaduan warga negara ke pengadilan konstitusi karena mendapat perlakukan (kebijakan atau tidak ada kebijakan) dari negara, dalam hal ini baik pemerintah, lembaga perwakilan rakyat, maupun Mahkamah Agung yang bertentangan dengan konstitusi dan merugikan hak-hak warga negara. Contitutional complaint hanya bisa diajukan setelah semua upaya hukum dilakukan melalui lembagalem-baga negara yang lain menemui jalan buntu (exhausted). Pada banyak negara, wewenang ini merupakan salah satu wewenang pengadilan konstitusi. Namun di Indonesia, UUD 1945 tidak secara tegas memberikan wewenang contitutional complaint atau pengaduan warga negara kepada Mahkamah Konstitusi (Zoelva, 2012: 158).

Pada saat pembahasan Perubahan UUD 1945 telah muncul usulan contitutional complaint sebagai salah satu kewenangan MK sebagaimana dikemukakan I Dewa Gede Palguna dalam Rapat Pleno Panitia Ad Hoc MPR RI, namun usulan tersebut ditolak dengan berbagai pertimbangan, antara lain tujuan utama pembentukan MK adalah sebagai lembaga judicial review UUD 1945, sehingga menghindari adanya penumpukan perkara, seperti dalam praktik yang terjadi di Mahkamah Konstitusi Jerman (Zoelva, 2012: 160). 
Menurut Huda, pada saat ini kewenangan Mahkamah Konstitusi tidak perlu ditambah dengan contitutional complaint, sebab MK sudah menangani perkara yang sangat banyak terutama tentang penyelesaian sengketa pemilihan kepala daerah. Sebaiknya MK fokus pada penyelesaian perkara pengujian Undang-Undang/judicial review dengan baik, sebab beberapa putusan MK akhir-akhir ini kualitasnya menurun. Pengaturan kewenangan constitutional complaint bukan kebutuhan yang mendesak pada saat ini. MK sebaiknya menata diri terlebih dahulu untuk mengembalikan kepercayaan masyarakat, setelah itu jika kepercayaan masyarakat sudah pulih dan kondisinya sudah memungkinkan, contitutional complaint bisa saja dimasukkan dalam kewenangan MK (Nugroho, 2015: 17).

Beda halnya dengan pendapatnya Sulardi, beliau menyatakan bahwa sejauh ini ada persoalan keadilan yang belum terselesaikan. Artinya terdapat berbagai kasus yang tidak mampu diselesaikan melalui jalur pengadilan, karena tidak masuk lingkup kewenangan lembaga-lembaga pengadilan yang ada. Oleh karena itu, contitutional complaint merupakan alternatif yang dapat digunakan oleh warga negara untuk memperoleh keadilan tersebut. MK seharusnya berani melakukan terobosan hukum untuk mengatasi kebuntuan. Ketika ada persoalan yang secara eksplisit tidak masuk dalam kewenangan MK maka MK harus berani memutuskan persoalan itu sebagai bagian dari konvensi ketetatanegaraan (Nugroho, 2015: 17).

Menurut pendapat Nanik Prasetyoningsih, mekanisme pengujian undangundang itu ada dua bentuk yaitu konkret dan abstrak. Pengujian yang bersifat konkret adalah pengujian terhadap regulasi/peraturan perundang-undangan yang diaplikasi-kan pada kasus tertentu, kemudian disebut contitutional question. Adapun pengujian yang bersifat abstrak artinya pengujian terhadap undang-undang (judicial review). Selain pengujian yang bersifat konkret dan abstrak di atas, ada pula istilah consti-tutional complaint (Nugroho, 2015: 17).

Menurut Nanik Prasetyoningsih, constitutional complaint urgen untuk diselenggarakan mengingat banyak persoalan yang tidak mampu diselesaikan oleh lembaga-lembaga negara yang lain, terutama di pengadilan dan pemerintah. Constitutional complaint bisa menjadi saluran bagi orang/person yang sudah mengajukan perkaranya melalui pengadilan tetapi belum mendapatkan kepuasan karena merasa belum mendapatkan keadilan (Nugroho, 2015: 17).

\section{Rumusan Pengaturan Constitutional Complaint dalam Kewenangan Mahkamah Konstitusi}

Mahkamah Konstitusi diberikan kewenangan limitatif hanya untuk menguji undang-undang terhadap Undang-Undang Dasar. Dengan demikian, terdapat pembagian kewenangan pengujian peraturan perundang-undangan (constitutional review atau legal review) antara Mahkamah Konstitusi dan Mahkamah Agung. Pembagian kewenangan pengujian ini seharusnya diterapkan juga dalam persoalan constitu-tional complaint. Artinya, apabila pokok persoalannya terletak pada kebijakan peme-rintah yang melanggar hak warga negara yang dijamin undang- 
undang ataupun ter-dapat perbuatan melanggar hukum, dapat diajudikasi melalui peradilan umum yang bermuara pada Mahkamah Agung (Zoelva, 2012: 160-161).

Sejak awal berdirinya hingga pertengahan tahun 2010, Mahkamah Konstitusi RI ternyata cukup banyak menerima pengajuan permohonan pengujian Undang-Un-dang yang secara substansial merupakan constitutional complaint, namun karena ke-wenangan MK yang tercantum dalam UUD 1945 tidak menyebutkan kewenangan constitutional complaint, MK tidak berwenang mengadilinya (Zoelva, 2012: 161).

Menurut Huda, jika constitutional complaint akan dimasukkan ke dalam kewe-nangan MK, maka harus dilakukan melalui amandemen konstitusi, sebab hal itu me-rupakan kewenangan baru yang berbeda dengan empat kewenangan yang telah ada. Pengaturan kewenangan constitutional complaint tidak dapat dilakukan melalui revi-si Undang-Undang Mahkamah Konstitusi, karena tidak memiliki landasan hukumnya (Nugroho, 2015:18). Namun sebenarnya, tanpa diatur secara eksplisit dalam per-aturan perundang-undangan, dalam praktiknya MK telah melakukan perkara judicial review yang mengandung unsur-unsur constitutional complaint dalam beberapa pu-tusannya (Nugroho, 2015: 18).

Berbeda halnya dengan pendapatnya Sulardi, untuk memasukkan kewenangan constitutional complaint di MK, tidak perlu amandemen konstitusi dan revisi UU MK, artinya tidak perlu ada legal formal, cukup melalui konvensi ketatanegaraan. MK sebagai salah satu lembaga kekuasaan kehakiman berwenang untuk membuat keputusan berdasarkan asas keadilan. Secara filosofis tujuan hukum itu ada 3, yaitu kepastian, keadilan, dan kemanfaatan. Ketiga hal tersebut bisa digunakan oleh hakim konstitusi untuk memproses perkara dan membuat putusan. MK boleh melakukaan ultra petita, yaitu bisa memutus lebih dari yang diminta oleh pemohon. Oleh karena itu hakim harus memiliki keberanian, sebagai contoh Hakim Sarpin yang berani memutus penetapan tersangka Budi Gunawan dalam sidang pra peradilan, padahal penetapan tersangka tidak menjadi obyek dalam prosedur gugatan praperadilan se-bagaimana diatur dalam KUHAP. Pada awalnya memang kontroversi tetapi selan-jutnya dihormati sebagai putusan yang dibuat oleh lembaga peradilan (Nugroho, 2015: 19).

Demikian juga pada awal kemerdekaan, Wakil Presiden Mohammad Hatta mengeluarkan Maklumat No. X yang sama sekali tidak diatur dalam konstitusi ternyata dapat diberlakukan. Begitu pula Dekrit Presiden 5 Juli 1959 yang dikeluarkan oleh Presiden Soekarno, malah justru bisa memberlakukan kembali Undang-Undang Dasar 1945. Pada masa sekarang ini, sebenarnya MK juga sudah menerapkan constitutional complaint, contohnya pada kasus pemilu presiden tahun 2009, yaitu pemilih boleh menggunakan Kartu Tanda Penduduk (KTP) pada saat memilih di TPS. Semen-tara di Undang-Undang tidak ada aturan yang mengatur tentang pemilih boleh memi-lih dengan Kartu Tanda Penduduk. Ini bukti bahwa keadilan dan kemanfaatan lebih diutamakan dibandingkan dengan kepastian hukum. Oleh karena itu untuk mene-rapkan constitutional complaint tidak harus diatur dalam konstitusi maupun undang-undang (Nugroho, 2015: 19). 
Senada dengan yang disampaikan oleh Sulardi, menurut Nanik Prasetyoningsih, kewenangan constitutional complaint tidak perlu secara eksplisit dimasukkan ke dalam norma hukum, yaitu konstitusi dan Undang-Undang, tetapi dengan cara melakukan perluasan makna judicial review atau pengujian undang-undang sebagai-mana yang diatur dalam Pasal 56-57 Undang-Undang No. 24 tahun 2003 tentang Mah-kamah Konstitusi (Nugroho, 2015:20).

Berdasarkan paparan di atas para pakar Hukum Tata Negara sesungguhnya sepakat dengan urgensi/pentingnya diadakan kewenangan constitutional complaint pada MK. Namun yang masih menjadi perdebatan adalah apakah kewenangan tersebut akan dimasukkan secara eksplisit ke dalam konstitusi/UU ataukah cukup digantungkan pada keberanian hakim MK dalam menafsirkan kewenangannya. Secara tek-nis, jika kewenangan constitutional complaint itu dimasukkan dalam kewenangan $\mathrm{MK}$, maka akan menambah beban MK dalam menyelesaikan perkara. Sedangkan secara yuridis, jika kewenangan tersebut dimasukkan pada level UU, akan ada persoalan karena tidak memiliki dasar hukum yang kuat dalam UUD 1945. Namun jika kewena-ngan tersebut dimuat dalam konstitusi membutuhkan proses yang panjang dan tidak mudah untuk melakukan amandemen konstitusi.

Pendapat yang moderat untuk mengatasi problem diatas adalah melakukan perluasan makna terhadap kewenangan MK, khususnya pasal yang mengatur pengujian undang-undang, yang tidak hanya terbatas pada menguji undang-undang semata tetapi juga menguji menguji norma dan implikasi berlakunya undangundang.

Pada praktiknya berbagai permasalahan konstitusional terkait implementasi undang-undang, kebijakan pemerintah yang melanggar hak konstitusional warga ne-gara, putusan peradilan umum yang saling bertentangan, dugaan penyimpangan da-lam penegakan hukum, hingga kelalaian pemerintah dalam penyusunan Daftar Pemi-lih Tetap Pemilihan Presiden merupakan beberapa perkara pengujian undangun-dang di Mahkamah Konstitusi yang secara substansial lebih ke arah constitutional complaint (Zoelva, 2012: 161).

Dengan demikian sesungguhnya MK secara substantif sudah mempraktikan penyelesaian constitutional complaint dalam beberapa perkara yang ditangani, oleh karenanya kedepan kewenangan ini perlu diperkuat dan dipertegas dalam undangundang, khususnya pada bagian bagian penjelasan Undang-Undang Mahkamah Konstitusi.

\section{E. SIMPULAN DAN SARAN}

\section{Simpulan}

a. Urgensi Pengaturan Constitutional Complaint dalam Kewenangan Mahkamah Konstitusi.

Mekanisme constitutional complaint penting dimuat dalam kewe-nangan Mahkamah Konstitusi untuk mengatasi problem ketidakadi-lan yang dialami 
oleh warga negara akibat kebijakan publik yang di-lakukan oleh pemerintah dalam arti luas yaitu eksekutif, legislatif maupun yudikatif.

b. Rumusan Pengaturan Constitutional Complaint dalam kewenangan Mahkamah Konstitusi.

Pengaturan constitutional complaint dalam kewenangan Mahkamah Konstitusi tidak harus secara eksplisit diatur dalam konstitusi, tetapi cukup dalam penjelasan Undang-Undang Mahkamah Konstitusi. Artinya tidak menambah secara langsung kewenangan MK, namun memperluas makna kewenangan MK dalam melakukan pengujian undang-undang.

\section{Saran}

a. Mahkamah Konstitusi dalam memutuskan perkara pengujian undangundang lebih diarahkan berorientasi pada mekanisme constitutional complaint.

b. Diperlukan pengaturan yang lebih jelas dalam Undang-Undang Mahkamah Konstitusi tentang pemaknaan constitutional complaint, meski tidak perlu ada penyebutan constitutional complaint.

\section{DAFTAR PUSTAKA}

\section{BUKU DAN JURNAL}

Aditya, Zaka Firma (2014). Kewenangan Mahkamah Konstitusi Dalam Menyelesaikan Perkara Constitutional complaint Berdasarkan UndangUndang Dasar Tahun 1945. Unnes Law Journal, Vol. 3, No. 1.

Arto, Mukti (2001). Konsepsi Ideal Mahkamah Agung. Yogyakarta: Pustaka Pelajar.

Asshiddiqie, Jimly (2011). Konstitusi \& Konstitusionalisme Indonesia. Jakarta: Sinar Grafika.

Fajar, Mukti (2006). Hukum Konstitusi dan Mahkamah Konstitusi. Jakarta: Konstitusi Press. J

Fatkhurohman et al. (2004). Memahami Keberadaan Mahkamah Konstitusi di Indonesia. Bandung: PT. Citra Aditya Bakti.

Handoyo, Hestu Cipto (2003). Hukum Tata Negara, Kewarganegaraan \& Hak Asasi Manusia. Yogyakarta: Universitas Atma Jaya.

KRHN dan LeIP (1999). Menuju Independensi Kekuasaan Kehakiman. Jakarta: ICEL.

Krisdanar, Vino Devanta (2010). Menggagas Constitutional complaint dalam Memproteksi Hak Konstitusional Masyarakat Mengenai Kehidupan dan Kebebasan Beragama di Indoneisa. Jurnal Konstitusi, Vol. 7, No.3.

Lutfi, Mustofa (2010). Hukum Sengketa Pemilukada di Indonesia: Gagasan Perluasan Kewenangan Konstitusional Mahkamah Konstitusi. Yogyakarta: UII Press.

Mahfud, Mohammad (1999). Pergulatan Politik dan Hukum di Indonesia. Yogyakarta: Gama Media. 
(2009). Konstitusi dan Hukum dalam Kontroversi Isu. Jakarta: Raja Grafindo Persada.

Marbun et al. (2009). Pokok-pokok Hukum Administrasi Negara. Yogyakarta: Liberty.

Muchsan (1981). Peradilan Administrasi Negara. Yogyakarta: Liberty.

Nugroho, Rahmat Muhajir (2015). Urgensi Pengaturan Perkara Constitutional Compalaint dalam Kewenangan Mahkamah Konstitusi. Laporan Penelitian DIPA Kopertis V Yogyakarta.

Siahaan, Maruarar (2012). Hukum Acara Mahkamah Konstitusi. Jakarta: Sinar Grafika.

Sutiyoso, Bambang (2009). Tata Cara Penyelesaian Sengketa di Lingkungan Mahkamah Konstitusi. Yogyakarta: UII Press.

Zoelva, Hamdan (2012). Constitutional complaint dan Constitutional Question dan Perlindungan Hak-hak Konstitusional Warga Negara. Jurnal Media Hukum, Vol.19, No.1.

\section{PERATURAN PERUNDANG-UNDANGAN}

Undang-Undang Dasar Negara Republik Indonesia 1945

Undang-Undang Nomor 24 tahun 2003 tentang Mahkamah Konstitusi 